\title{
The Itinerant Illustration: Creating storyworlds in the reader's space
}

Steve Braund

Imagine if you will an illustrated story, comprising of still images and text, with all its characters, plotline and narrative tension, but the world of that story [the diegesis], extends outwards from the printed page [or e-book], into what I am going to call here, the reader's space.

This paper explores the storytelling potential of direct address [otherwise known as breaking the fourth wall], by which I mean moments where fictional characters look out from their still-image world, whether picture-book, graphic novel or comic, into ours. It will consider the possibility of creating fictional worlds by employing direct address to generate narrative in the real time and space of the reader.

This phenomenon is at the core of games design, where, through interactivity, real-time moving-image and sound, aim to give their audience the experience of actually being in the story itself. According to Professor of Digital Games, Tanya Krzywinska, 'Digital games trade on putting you in a position of the "other", on inhabiting a character's perspective, on presenting multiple points of view.' There are many examples like Minecraft, Skyrim, and World of Warcraft that demonstrate the storytelling prowess of digital gaming.

There are games you can play, put down and return to, like Everquest, DOTA and League of Legends, known as jump-in, jump-out games. And one of the best examples is the earlier PS Vita system game, Tear-away, where the hand-held device has a back-plate and hand-roll for the players fingers, which then appear within the game transposed onto the screen along with real-time video of their face as they play.

So, if gaming does it so well, why bother going any further?

Because, I would argue, something is missing. For in gaming, as in film, it's all done for you, seamlessly, with little space to ponder or imagine. Digital gaming works on storytelling-linearity and simulation. In my interview with Professor Krzywinska, she stated that 'Digital games don't allow you to imagine much precisely because they are simulations. The literal construction of space is integral to the games medium because it seeks to simulate.' Games aim to maximise simulation and believability, and it's this very seamlessness that constrains the audience's ability to enter an imaginative process.

Sequential, still-image, storytelling presents us with narrative fragments, and I would argue that these sequences are particularly powerful in stimulating our imagination. Still images with supportive text invite their audience to perform their own act of closure between the images. We have to use our own imagination to form the story. I think there is something profoundly important about this precisely because these sequences demand an effort to read, as opposed to the passive experiencing of immersive moving-image and sound, 
although digital games do demand an effort of a different kind, one that is about practical problem solving and translating intention into hand-eye coordination. 1

We read still images and text at our own pace, we have to perform closure as the storyworld is not given to us on a plate. Details of space, time, characters, actions, and environments, require our active participation, and that empty space between pictures is key. These visual and affective imaginings can tap into our own personal history - while games provide all the images and the affect is largely reactive.

Mieke Bal has described how the Russian critic Jurij Lotman pointed out the predominance of the dimension of space in human imagination, explaining how our language uses spatial words to describe abstract concepts such as, 'distance' to describe a failing relationship, or 'infinite' for an immeasurably large quantity. Bal stating that 'When the location has not been indicated, readers will, in most cases, supply one. They will imagine the scene, and in order to do so, they have to situate it somewhere.'

What I will try to show is that it is possible to encourage an audience to situate the storyworld as unfolding directly in their own temporal and spatial reality: To consider the idea of creating fictional worlds flexible enough to incorporate instances in which the characters in picture-books, graphic novels or comics, whether print or e-book, might be said to look directly out of their pictures, and communicate messages to the reader who then generates a narrative in their own physical space and time.

The creative transition I wish to attempt is from conventional still-image narratives, where we use our imagination to construct the story in our minds, to instances which transgress the distinction between this enclosed fictional experience and our present time and space reality. In so doing, we can construct a metaphor that poses questions about the relationship between fiction and reality. Employing illustration to explore the fictionality of the world outside the graphic/literary fictional text: Perhaps to contemplate the construction of reality itself. Indeed, an interesting question arises in gaming, film, theatre and in picture-books: Where is the fictional storyworld [the diegesis]? Is it in the game, in the movie, on the stage, in the picture-book, or has it bled into our reality?

Direct address is very common in comics. A great example being Grant Morrison whose work includes some of the most influential works in comics history from Animal Man to his new project, The Multiversity. Morrison, as the writer, inserts himself into the end of his Animal Man comic where he explains everything about the story to his character Animal Man.

But these comics, in breaking the fourth wall, as far as I have observed, only pull us in to their world, the effect is seen and read on the printed page. To date, I have found no examples where comics construct a story by projecting narrative signifiers outwards to the real time and space that we the audience occupy.

1. There are some games that go counter-wise to this like The Stanley Parable or The Path. 
Most picture-books construct their audience as absent from the fictional characters. But I would suggest that a coherent diegesis can be established through direct address which constructs its audience as present with the fictional characters. To attempt to construct a completely separate narrative in the reader's space, one that bears no relation to the one in the book being read, would involve careful encoding and, whilst I think it is possible, it would lose so many storytelling possibilities that the interaction between the illustrations and the reader's space offer, as to seem less attractive.

The idea of creating storyworlds in the reader's space relates of course to Brecht's idea of showing showing, where his actors break through the 'fourth wall': the audience constantly aware they are watching a play; the structure of their experience laid bare. It is interesting to explore showing showing from an illustration perspective, where the reader experiences the construction of the conventional picture-book fiction 'laid bare' giving rise to the realisation that they are being watched by that which they are watching. Not only that, but to propose that it is possible to construct a story in the reader's space, which has direct implications for the reader themselves, one that is in effect illustrated by the illustrations they are viewing; making the illustration the illustrator and the audience the illustrated.

In his book Breaking the Fourth Wall: Direct Address in the Cinema, Tom Brown has described ' ... the ontological strangeness of direct address as moments in which fictional characters look out of their world into ours ... .' Brown reminds us, that the fourth wall, being a theatrical convention, led early cinema to the natural adoption of a 'vaudevillian' engagement with its audience as many cinemas were set up in vaudeville theatres [from around the beginning of the 20th Century]. This was known as the 'cinema of attractions'. But this period was increasingly seen as being primitive as 'attractions-based cinema' gave way to 'cinema of narrative integration,' and the cinematic world developed a more coherent diegesis. As Brown points out [in the early years of film] 'narrative "immersion" might often be put aside in favour of a direct assault on the spectator's more physical reactions, their emotions, sense of humour, and so on.' 2

Another critical writer in film studies, Tom Gunning (Brown, T.) has described how, despite the introduction of editing and more complex narratives, the cinema of attractions persisted in later cinema providing an underground current floating beneath narrative logic and diegetic realism.3 However, counter to Gunning's statement and key to this paper's hypothesis Brown comments that,

'... the continuation of direct address throughout cinematic history need not be explained by the logic of "attractions"; ' ...direct address can be more than just the blunt, verbal communication of themes and feelings.' ... 'direct address may enhance a "coherent diegesis", rather than be opposed to it.'

\footnotetext{
For an early example of cinematic breaking of the fourth wall see Edwin Porter's 1903 film The Great Train Robbery where George Barnes fires his pistol directly at us, the audience.

For more recent examples see the art house cinema of directors like Jean Luc Godard.
} 
So let us consider not only the acknowledgement of our presence as spectators but the active involvement of us, the audience, in the unfolding fiction.

What I am proposing is, of course, a type of metafiction, a term, as defined by Patricia Waugh, '... given initially to fictional writing which self-consciously and systematically draws attention to its status as an artifact in order to pose questions about the relationship between fiction and reality.

As Waugh points out:

'... In providing a critique of their own methods of construction, such writings not only examine the fundamental structures of narrative fiction, they also explore the possible fictionality of the world outside the literary fictional text.'

It's not a great leap to think of these questions being explored through fictional illustration or perhaps of adopting a term like 'metagraphic-fiction.' Waugh suggests that if our knowledge of this world is now seen to be mediated through language, the literary fiction [or, graphic literary fiction] worlds constructed entirely of language, become a useful model for learning about the construction of reality itself. 'Metafictional - self-conscious - texts suggest the ways in which our sense of reality is similarly fabricated.' (Patricia Waugh, 1996).

Although the term metafiction is a recent one, the phenomenon has been around for centuries. An early example being the novel, The Life and Opinions of Tristram Shandy, Gentleman. In Laurence Sterne's Eighteenth Century comic masterpiece, the reader 'is there too' so to speak. In the opening scene Sterne famously has his character Shandy conversing with us the reader. Crucially, we, the reader are made to feel responsible. Significantly, in Tristram Shandy, Sterne has the reader not just in conversation with the fictional Shandy, but their conversation reveals details of the reader's [our] supposed identity, implicating the reader and drawing them into the fiction.

Waugh [Brown 2013, p.4] describes how 'a metalanguage [Hjelslev's term] is a language that functions as a signifier to another language, and this other language becomes its signified' - 'Metafictional practice is evident in that the work consistently displays its conventionality, which explicitly and overtly lays bare its conditions and artifice, and thereby explores the problematic relationship between life and reality' [ibid]. What this article is proposing is to display the process of a picture-book's construction, as with David Wiesner's adaptation of The Three Pigs, in order that the conventional construction is revealed, freeing it to signify another language, a metafiction, through direct address, which can take the story into the reader's space. 


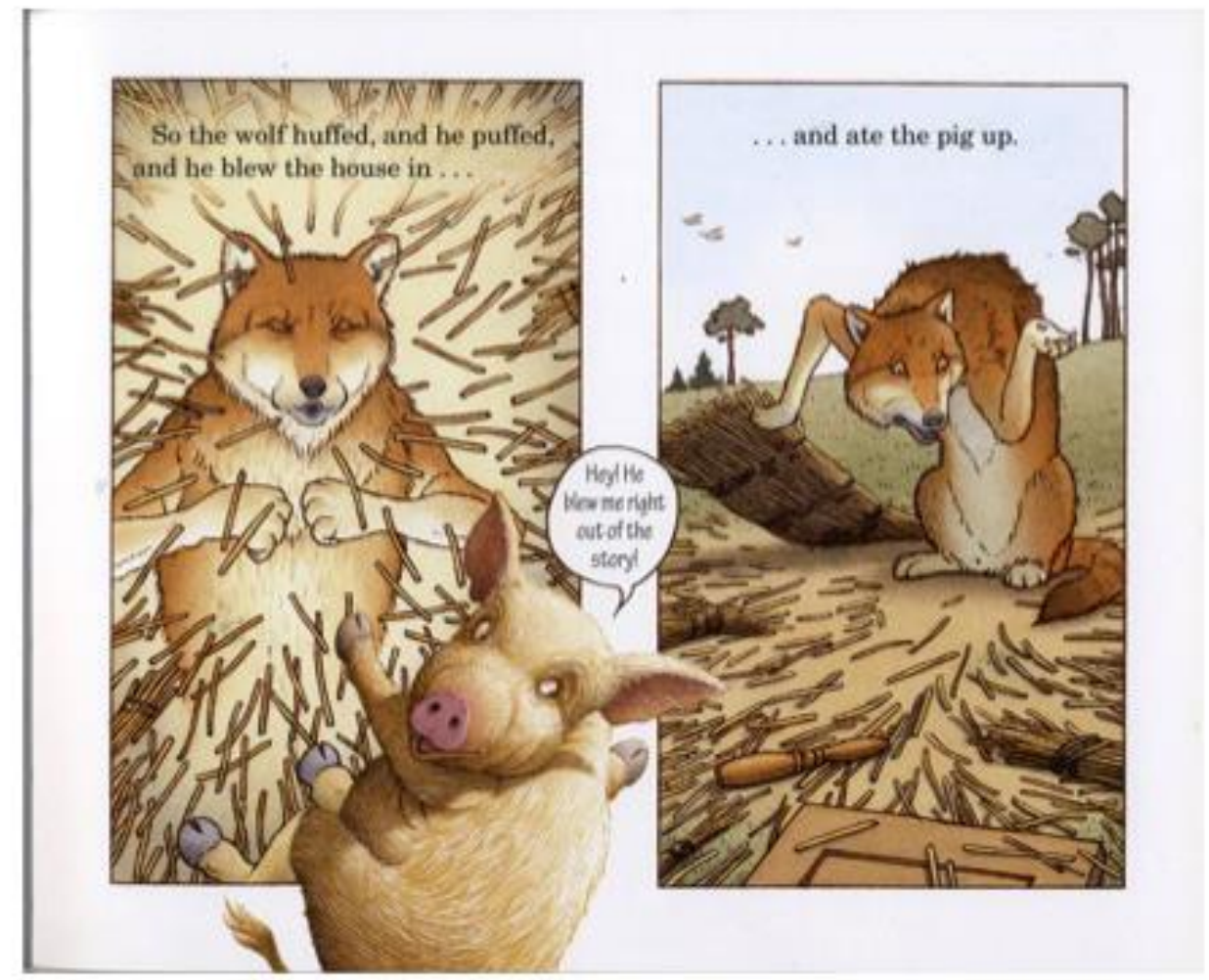

Figure 1: 'Hey! He blew me right out of the story.' From David Wiesner's The Three Pigs.

In Laura Mulvey's essay Visual Pleasure and Narrative Cinema (Screen, 1975), her use of the word 'magically' to describe conventional cinematic representation echoes Brecht's own description of [mainstream] cinema's 'witchcraft'. The easy separation between text and spectator is precisely what Brecht sought to counter in his epic theatre via direct address and distanciation.' (Brown, p.7). I wondered if illustrated picture-books had ever been considered in this way.

Tranposing a passage in Mulvey's essay about the three different looks associated with cinema, and applying them to the picture-book describes an equivalent three looks: that of the artist's gaze as he/she creates the work; that of the audience as it reads/views the final product; and that of the characters looking at each other within the pictorial illusion (an intra-diegetic look). The conventions of narrative deny the first two, the conscious aim being always to eliminate intrusive creator, reader/viewer presence and prevent a distancing awareness in the audience, forever mesmerizing them into a suspension of disbelief.

But what if we push the storyworld further, right out into the space occupied by the audience, until we establish a narrative there? This would give us a fourth look: that of the characters and the reader at one another. Our suspension of disbelief might momentarily collapse, with a brief sensation of distancing, to be re-suspended within the reader's space, creating cross-diegetic storytelling. This appears to be unexplored in picturebooks. 
I found three examples of direct address employed in interpretations of the story, The Three Little Pigs: In Tony Ross's The Three Pig's the wolf is depicted stealing a cunning glance directly at us, the audience. In John Scieszka and Lane Smith's The True Story of the Three Little Pigs, the character of the wolf directly addresses us with his own [rather dubious] version of what really happened with the three pigs. And in David Wiesner's adaptation, The Three Pigs, whilst still limited to the confines of their pages, the pigs break out of their panels and see beyond the page constraint to us the audience, as one pig exclaims, 'I think ... someone's out there.'

In Bryan Talbot's graphic novel Alice in Sunderland, Talbot has Tweedledum and Tweedledee directly addressing the audience. Tweedledum says, 'If he wakes up, you won't exist. Tweedledee says 'We won't exist,' - and pointing to us, the audience, he adds - 'They won't exist.' Talbot gets close to constructing a narrative in the reader's space but, I would argue, he is pulling us in to the narrative that is taking place in the book, implying we are characters sitting in the theatre where he sets his story. In think Alice in Sunderland expresses different levels of dreaming, rather like the film Inception. In so doing, Talbot takes himself as creator, like Grant Morrison, into his illustrated fiction. I would argue that Talbot is questioning our perception rather than generating a narrative in the reader's space.

In another example, in the infamous Tank Girl series by Hewlett and Martin, the title's punkish protagonist often looks out of the picture and talks to us, usually in a derogatory tone. But in so doing, she gives us information about our [apparent] circumstances.

When one of my postgraduate students, Emilia Wharfe, told me that Imble, one of her characters could see her audience, I immediately signed her up as my research assistant. Emilia and I are now developing an illustrated book using this concept in which twin sisters Nimble and Imble, a latter day Tweedledum and Tweedledee, attempt to project a story into the present time and space of the reader, whilst simultaneously performing a story within the book. 


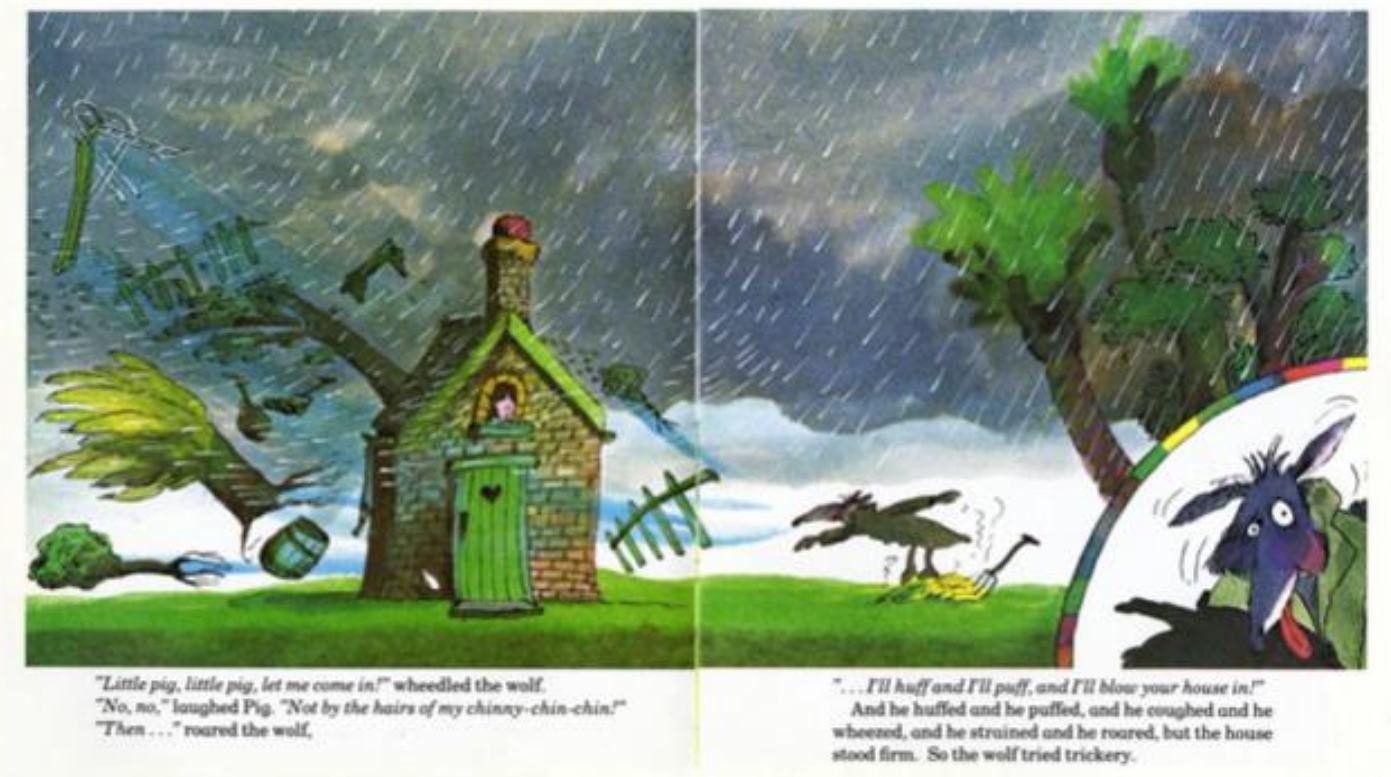

Figure 2: 'Little pig. Little pig, let me come in!' from Tony Ross's The Three Pigs.

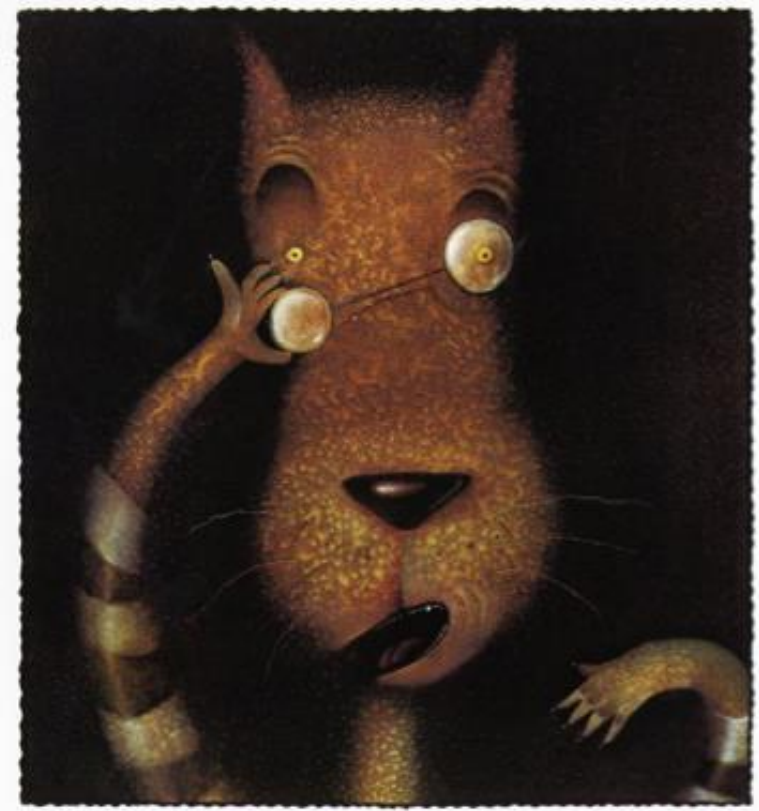

Im the woll. Alexander T. Woll

You can call me Al.

I don't know how this whole Big Bad Wolf thing got started, bet it's all wrong.

Figure 3: 'Alexander T. Wolf' from John Scieszka and Lane Smith's The True Story of the Three Little Pigs (1989). 


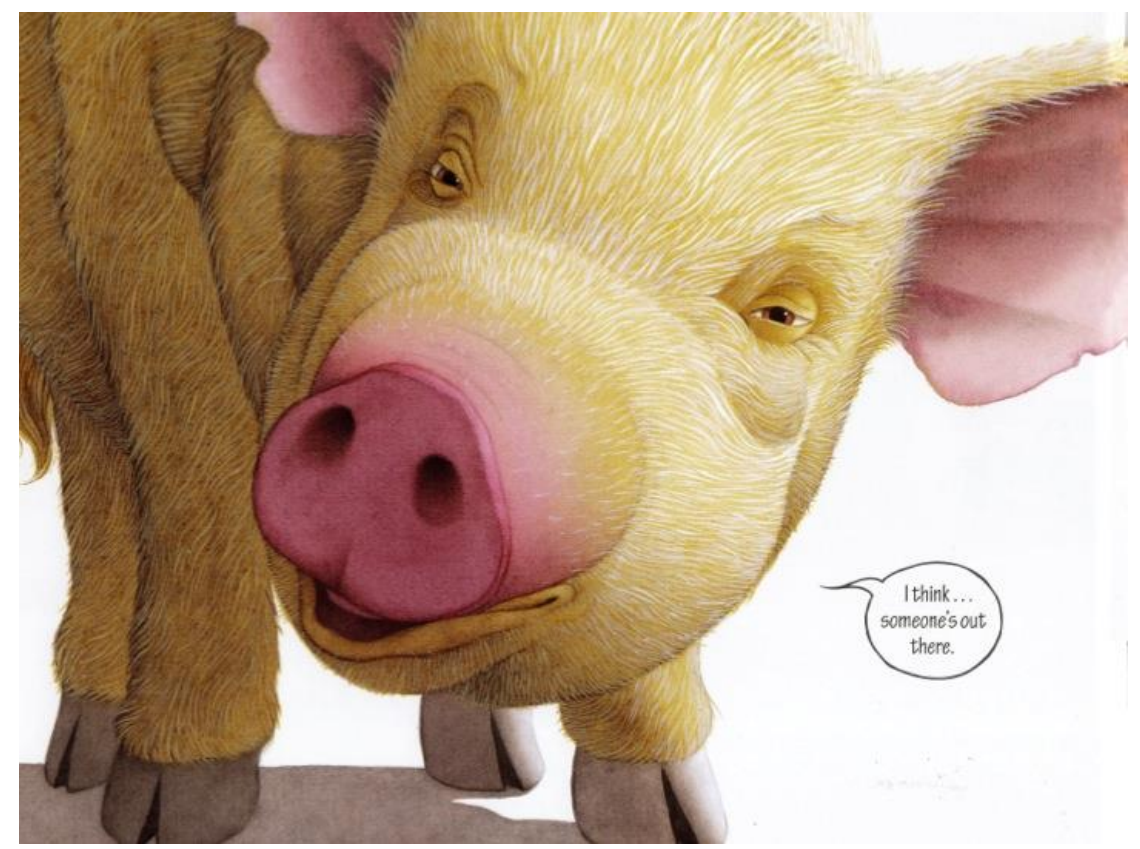

Figure 4: 'I think ... someone's out there', from David Wiesner's The Three Pigs (2001).

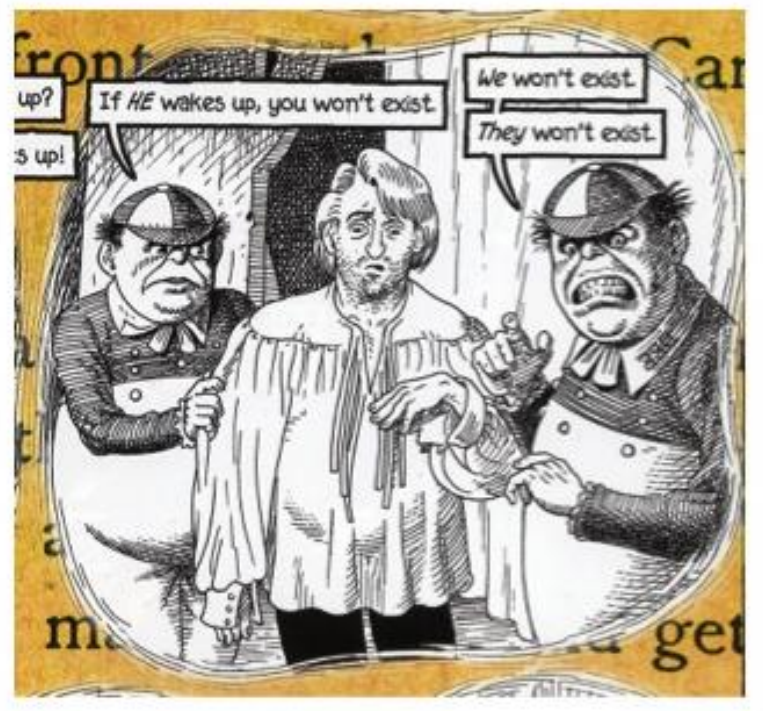

Figure 5: Tweedledum and Tweedledee, from Bryan Talbot's Alice in Sunderland. 


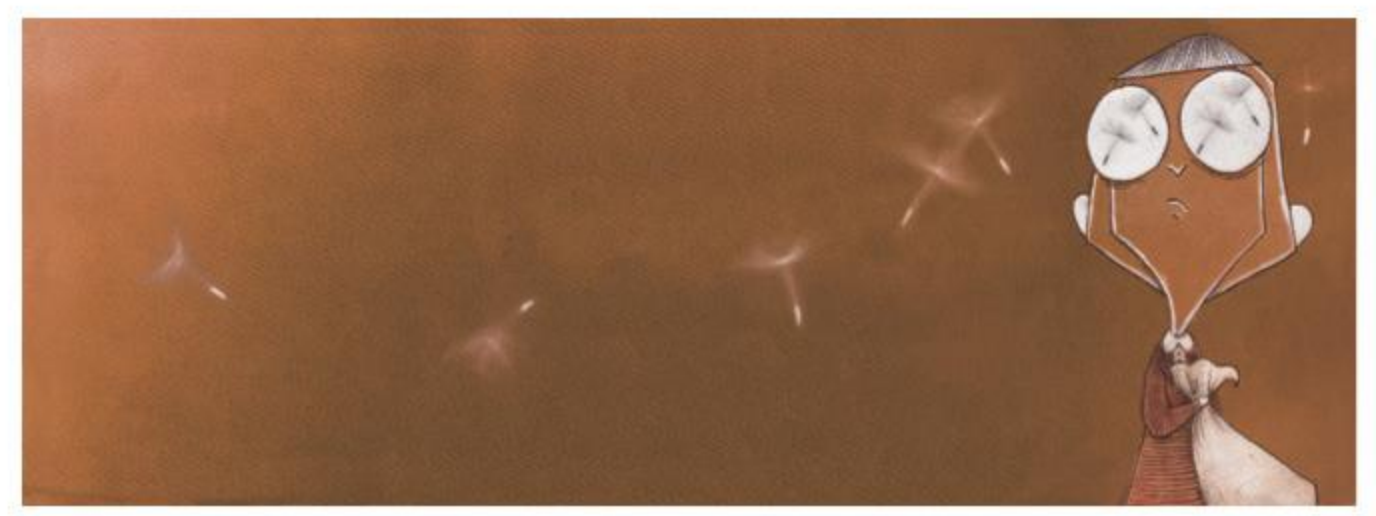

Figure 6: Imble's glasses reflect seeds from the reader's space, from Emilia Wharfe's The Red Haze.

With this kind of concept, all signifiers are, of course, subject to the reader's validation. If any signifier attempting to project a narrative into the reader's space can be rejected, the illusion will collapse. Therefore the signifiers must suggest things or experiences that the audience cannot easily verify as untrue. The possibilities comprise of the senses [especially invisible instances], and the signification of thoughts or emotions, as they too can remain invisible. So, we chose to employ vision, hearing, touch, ideas and emotions. We decided to signify the breath, as the breath is always in the present and therefore helpful in maintaining a narrative in the present time and space of the reader.

Crucial to our understanding of the plot, Nimble tells us that just as we the reader can see things happening in the pages of illustrated books that the characters in those books cannot see, so too some fictional characters have the ability to see things happening in our reality than we cannot. Using this principle, and with a nod to Van Eyke's The Arnolfini Wedding where a mirror shows the audience looking at the work, we decided to employ Imble's large round glasses to reflect things that we the reader are told Imble can see happening in our own time and space, that we ourselves are unable to see.

In our picturebook, The Red Haze, the characters Nimble and Imble are fleeing from a deadly haze which is sweeping across their land, like an advancing army. 4 The haze is formed of millions of tiny seeds which, if we are exposed to them, 'seed' in our imagination, placing us into a deep state of delusion where we lose all sense of reality and our life becomes nothing more than a dream. In homage to Alice's Adventures in Wonderland, the book's cover carries the warning: 'Do not open me!' 


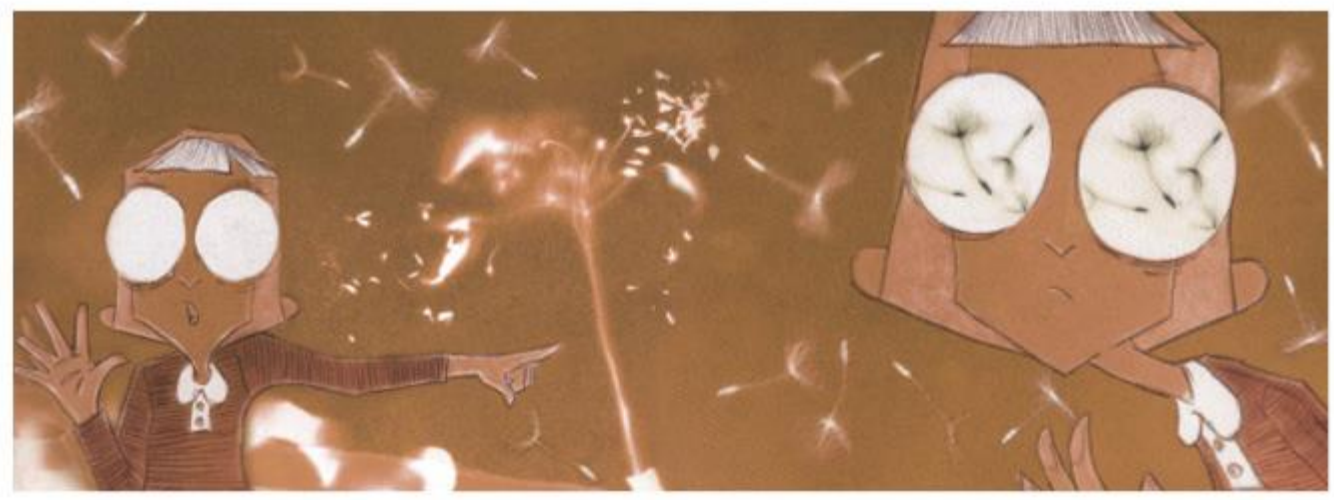

Figure 7: Nimble and Imble panic, from Emilia Wharfe's The Red Haze.

Of course, we are intrigued and open the book, immediately to be met by a panicking Nimble and Imble who frantically warn us that in so doing we have let the awful haze out of the book to infect our reality. A drama ensues.

Imble has the ability to see us the reader, but is unable to speak to us, [Imble is an autistic savant], and so whispers into her twin sisters ear, who in effect narrates the story. In an attempt to help us, the audience, Nimble rushes around in further panic trying to capture the seeds in jam jars before they can infect our world.

4. Red is a reference to the red army that advanced across Finnish territory during the Second World War.

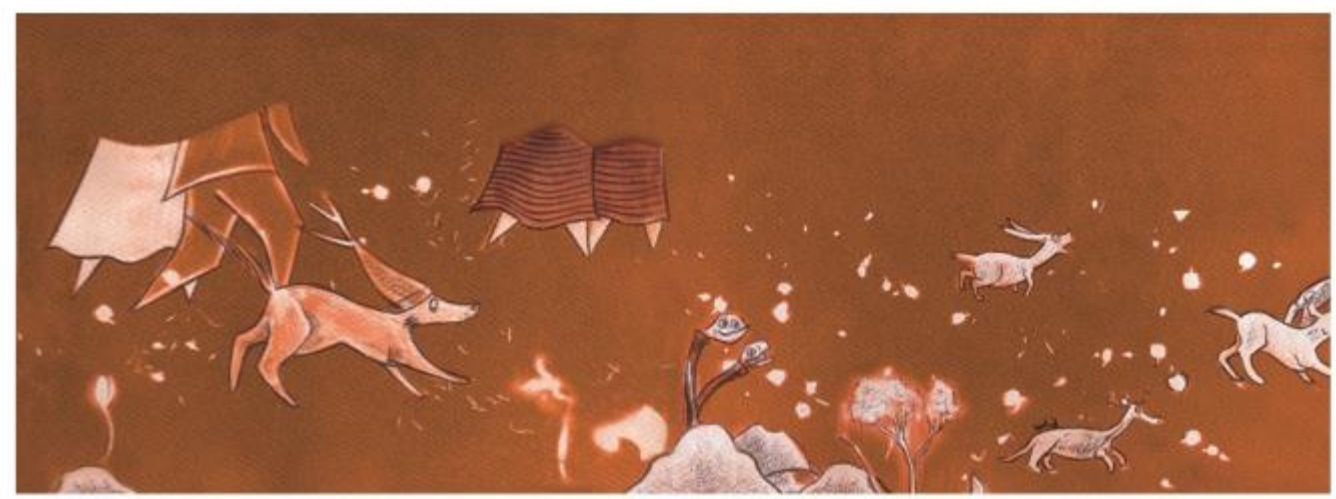

Figure 8: Deluded animals float by, from Emilia Wharfe's The Red Haze. 


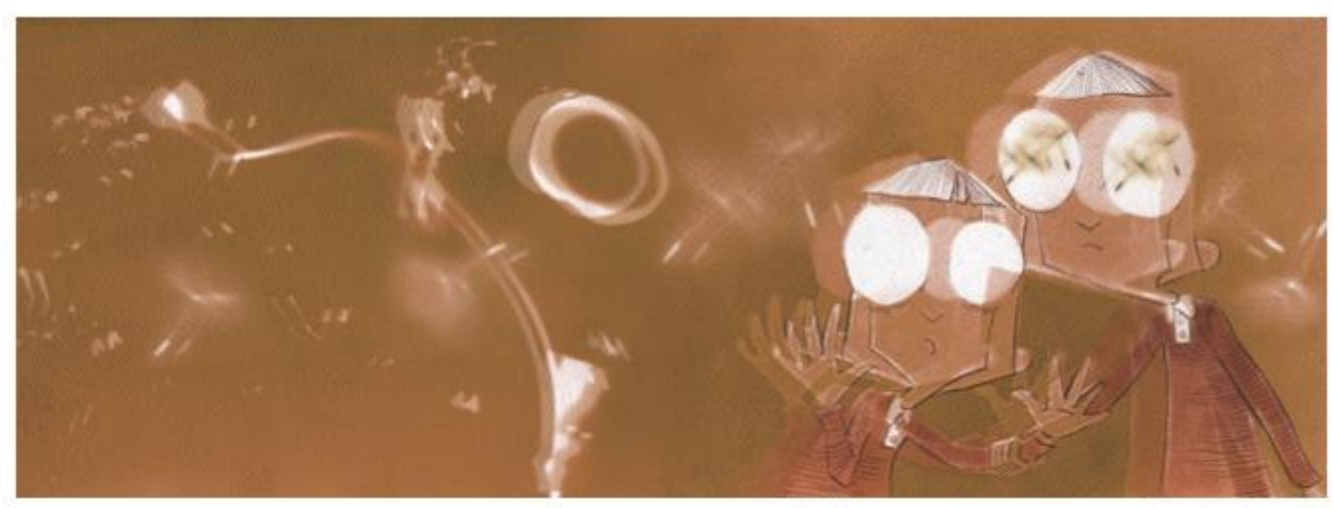

Figure 9: Blurred vision, from Emilia Wharfe's The Red Haze.

Already infected by the red haze, deluded animal characters float lost in an endless dream. Nimble tries borrowing her sister's glasses to see what it is that her sister can see, but she cannot make anything out. So, Nimble starts searching for other optical devices.

Nimble tells us, the reader, that a symptom of the haze entering our space and infecting us would be that our vision might become blurred. As her sister whispers into her ear, Nimble asks us to pay close attention to what she is about to tell us. She says that the only way to disperse the deadly haze is to concentrate all our attention on our breathing: the breath coming in and the breath going out. This Nimble tells us, will hold our imagination in the present moment, not allowing the delusion to envelop our minds, and that if we keep observing the breath as we read the book the haze will hopefully disperse. We, the reader, follow this request by watching our breath, thus taking an active part in the fiction.

At the end of the book Nimble comes across an old seaside telescope that she puts a coin into and is finally able to see us the reader, announcing, with great relief, that the mist has cleared from our reality and all is well [But suggesting we quickly close the book to prevent the deadly haze returning].

To conclude, what I have been describing is still images in sequential storytelling where closure, as described by Scott McCloud in Understanding Comics [notable for its own use of direct address], is the enabler of the imaginative experience. In moving image, closure is, as McCloud suggests, over-powering, as our minds 'aided by the persistence of vision, transform a series of still pictures into a story of continuous motion.' I would argue that this over-powering closure leaves the true potential of the imagination hidden. Moving image in digital gaming sets up a series of interactive choices which draw the player in, to feel as though they are enveloped within the storyworld. But this has the effect of pulling them inwards, into the story, rather than the story projecting outwards into their own reality. 


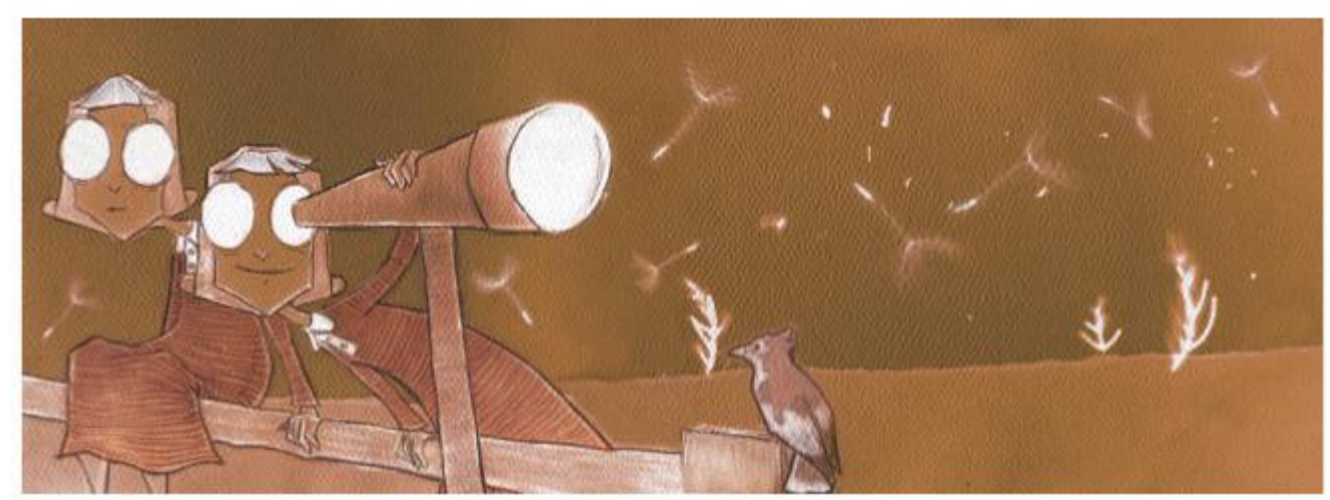

Figure 10: Nimble looks through the telescope, from Emilia Wharfe's The Red Haze.

McCloud states [ibid] that 'Between such automatic electronic closure and the simpler closure of everyday life there lies a medium of communication and expression which uses closure like no other.' He describes this as the 'space between two comics panels, the gutter.' Influenced by comics and graphic novels, these panels appear more and more in our contemporary picture-books, where it is clear also that the page-turn performs a similar function and, in McCloud's words, the reader is 'a willing and conscious collaborator and closure the agent of change, time and motion.' Crucially, as McCloud explains, nothing is seen between the two panels, but experience tells us something must be there. And the same can be said of the page-turn in picture-books. McCloud states that visual iconography is the vocabulary of comics, and closure is its grammar, and picture-books clearly work in a similar way.

Returning to our 'itinerant illustrations', this projecting outwards, this migration of story, might leave the story that remains on the pages either hard to follow, in a state of collapse, or simply redundant. The outward-moving itinerant illustrations may be incompatible with the inward experience on the page. In terms of proving that the migration of the story is possible this collapse doesn't matter, but if we want to create a fully integrated narrative experience we will want the reader/viewer's interest to engage both 'within' the picture-book and 'outwardly' to consider that they themselves are entangled within a story experience. But not in the sense that a digital game might place you within an illusory space and time, because here the story is unfolding in your time, your space, and your reality.

In Brown's survey [T. Brown, 2013], he states that, ' ...direct address can be more than just the blunt, verbal communication of themes and feelings.' Transposing Brown's filmic comments onto the field of picture-books, we can say that, Direct address also encompasses wordless examples, where eye-line, gesture and the characters' bearing combine with other elements to express unsayable things. In other examples, there is a complex, ambiguous relationship between what is said and what the direct address of the characters perform.

Brown's examples of the signifying functions of expression through direct address in film easily map onto the world of picture-books and, I suggest, offer 
possibilities for extending the scope of picture-books. Although too detailed to describe here, they are: Intimacy, Agency, Superior epistemic position within the fictional world [Imble's superior knowledge], Honesty, Instantiation, Alienation and Stillness.

Brown makes a pertinent observation that, '... there is no contradiction between our emotional involvement with fictional characters and their addressing us through the apparatus of the camera. Precisely the opposite: direct address may enrich our appreciation of fiction and its characters.' There is much mention in histories of early cinema of direct address puncturing the fictional illusion, but I want to suggest that here also we may have missed the opportunity to consider the possibility of the fictional illusion being generated within the viewer's own space; direct address being the communicative catalyst.

Brown reminds us that, 'cinematic direct address can only ever feign the contact between actor and spectator common to theatre,' the film [and the same can be said of picture-books] having been created some time before. Where of course theatre commonly pierces the fictional illusion by interacting with its audience as in the epilogue to Shakespeare's The Tempest, where Prospero directly addresses the audience imploring them to set him free from the spell they have him under by putting their hands together in applause.

So, what of the more distanced graphic illusion of the picture-book where the actors [the characters] constructed in their creator's imagination materialise in printers ink on paper [or digital pixels in e-books]? Not only do they feign the contact between character and spectator, which, as in film, is a material impossibility, but being entirely fabricated in the imagination they can only mimic the experience of direct contact. Interestingly however, the illusion of direct address still holds, similar to the way the human brain reacts to dreaming as it does to reality; being unable to distinguish one from the other and experiencing the same emotional reactions.5

In the case of direct address in cinema the actor looks into the camera and subsequent viewing creates the illusion of eye-to-eye contact with the audience. In the case of picture-books the illustrator must first have the characters look into the eyes of their creator for subsequent viewing to create the illusion of eyeto-eye contact with the audience.

If comic books and graphic novels typically require closure by the reader between panels and picture-books rely more heavily on closure by the reader from one image to the next through the page-turn, then direct address within picture-books requires closure by the reader between what is read and viewed, [held in their hands] and their own implication within the fiction. The piercing of an illustrated illusion into our present reality provides a ground, at least, for constructing an implied narrative in the reader's space, in real time.6

Characters looking out at the reader/viewer would seem to disrupt the illusion of the story world. But as Brown suggests, taking the example of cinema, this form of direct address can intensify our relationship with the fiction. I would add 
that if you can create at least two signifiers through direct address the reader/viewer will create closure between those two, providing the foundation for a new kind of intensification of our relationship with the fiction.

To reiterate Brown's point: 'there is no contradiction between our emotional involvement with fictional characters and their addressing us through the [delayed] apparatus of the camera.' And, I would argue, the same is true of illustrations. As Brown says: 'Direct address may enrich our appreciation of fiction and its characters,' ... and it 'may enhance a "coherent diegesis", rather than be opposed to it.'

\footnotetext{
5. It could be argued that video games occupy a middle ground here (by virtue of their simulated environments) and table-top role-playing games - which is part board game and part am-dram.

6. Nathalie Op de Beeck, 'On Comics-Style Picture Books and Picture-Bookish Comics. Children's Literature Association Quarterly, 37 (2012).
} 


\section{References}

Bal, M. (1985) Narratology, Toronto, University of Toronto Press

Brown, T. (2013) Breaking the Fourth Wall: Direct Address in the Cinema, Edinburgh, Edinburgh University Press

Liefeld, R./Nicieza, F. (1991) Deadpool, Los Angeles, Marvel Comics

McCloud, S. (1993) Understanding Comics, New York, Harper Perennial

Moore, A./ Gibbons, D. [1987] The Watchmen, Los Angeles, DC Comics

Op de Beeck, N. (2012) On Comics-Style PictureBooks and Picture-Bookish Comics., Children's Literature Association Quarterly, 37 (2012), Baltimore, John Hopkins University Press

Morrison, G. (1989)_Animal Man, Los Angeles, DC Comics

Morrison, G. (2014) The Multiversity, Los Angeles, DC Comics

Mulvey, L. (1975) Visual Pleasure and Narrative Cinema , Published - Screen 16.3 Autumn 1975 pp. 6-18, Oxford, Oxford Journals

Porter, E.S./Fleming (1902) Burlesque Suicide no.2, u-tube https://www.youtube.com/watch?v=FT9wrw4yGBU

Porter, E.S. (1903) The Great Train Robbery, u-tube, https://www.youtube.com/watch?v=r0oBQIWAfe4

Ross, T. (1987) The Three Pigs, London, Andersen Press.

Scieszka, J./ Lane Smith, L. (20?) The True Story of the Three Little Pigs, New York, Harcourt and Brown

Sterne, L. The Life and Opinions of Tristram Shandy, Gentleman1, BBC Radio 4, In our time 24.04.14, Melvyn Bragg

Waugh, P. (1996) Metafiction' Theory and practice of self-conscious fiction, London, Routledge

Wiesner, D. (2001) The Three Pigs, New York, Houghton Mifflin Harcourt.

\section{Acknowledgement}

Interview with Professor Tanya Kryzwinska (July, 2014): Professor of Digital Games, Tanya Krzywinska, Falmouth University. 


\section{Illustrations}

Figure 1: 'Hey! He blew me right out of the story.' From David Wiesner's The Three Pigs.

Figure 2:

'Little pig. Little pig, let me come in!' from Tony Ross's The Three Pigs, London, Andersen Press.

Figure 3: 'Alexander T. Wolf' from John Scieszka and Lane Smith's The True Story of the Three Little Pigs, Harcourt and Brown.

Figure 4: 'I think ... someone's out there,' from David Wiesner's The Three Pigs, New York, Houghton Mifflin Harcourt.

Figure 5:

Tweedledum and Tweedledee, from Bryan Talbot 's Alice in Sunderland.

Figure 6: Imble's glasses reflect seeds from the reader's space. From Emilia Wharfe's The Red Haze.

Figure 7:

Nimble and Imble panic, from Emilia Wharfe's The Red Haze.

Figure 8: Deluded animals float by, from Emilia Wharfe's The Red Haze

Figure 9: Blurred vision, from Emilia Wharfe's The Red Haze

Figure 10: Nimble looks through the telescope. From Emilia Wharfe's The Red Haze. 